\title{
Developmental competence and oxidative state of mouse zygotes heat-stressed maternally or in vitro
}

\author{
M. Ozawa, M. Hirabayashi and Y. Kanai* \\ Institute of Agriculture and Forestry, University of Tsukuba, \\ Tsukuba-shi, Ibaraki 305-8572, Japan
}

\begin{abstract}
Mammalian preimplantation embryos are sensitive to maternal and direct heat stress. However, the mechanisms by which heat stress affects early embryonic development in vivo or in vitro are unknown. This study examined whether heat-stress-induced loss of developmental competence in mouse embryos was mediated by physiological changes in the maternal environment or by high temperatures alone. After fertilization, zygotes at the same stage were heat-stressed at $39.5^{\circ} \mathrm{C}$ for $12 \mathrm{~h}$ either maternally (measured by maternal rectal temperature) or directly in culture. Zygotes in each group were cultured at $37.5^{\circ} \mathrm{C}$ for a further $84 \mathrm{~h}$ to assess their developmental ability. Neither type of heat stress affected the first cleavage rate. However, the proportion of embryos that developed to
\end{abstract}

\section{Introduction}

Mammalian preimplantation embryos are sensitive to high temperatures. Maternal heat stress, or the resultant hyperthermia, leads to an increased loss of early stage embryos (Edwards et al., 2001). The heat-stress-induced loss of early embryos has been well documented in farm animals, the susceptibility to heat stress of which has increased together with their productivity (Cavestany et al., 1985; Hansen et al., 2000). Lactating dairy cows with high milk yields are the most sensitive to hot environments because of their high metabolic rates and they become hyperthermic at air temperatures as low as $27^{\circ} \mathrm{C}$ (Berman et al., 1985). As a result, infertility caused by heat stress is more severe in lactating cows than in non-lactating heifers (Ingraham et al., 1974; Badinga et al., 1985). It is also notable that the effect of hyperthermia on preimplantation embryos appears to be more pronounced at the zygote than at the morula or blastocyst stage (Edwards et al., 2001). Exposing lactating cows to a hot environment on the day of insemination significantly reduces the proportion of embryos that develop into blastocysts, whereas the same heat stress at day 3 or day 5 after insemination has a minimal influence on embryonic development (Putney et al., 1989; Ealy et al., 1993). The vulnerability of early cleavage-stage embryos to maternal hyperthermia has been reported in a wide range of

*Correspondence

Email: kanaiy@sakura.cc.tsukuba.ac.jp morulae or blastocysts was significantly lower in the maternally heat-stressed group, but not in the directly heat-stressed group. Moreover, maternal heat stress significantly reduced intracellular glutathione concentrations and enhanced hydrogen peroxide concentrations in both zygotes and two-cell embryos that were recovered immediately after heat stress or $\mathbf{1 2} \mathrm{h}$ later, respectively. In contrast, direct heat stress had little effect on concentrations of glutathione or hydrogen peroxide in cultured early embryos. These results demonstrate that maternal heat stress at the zygote stage reduces the developmental ability of mouse embryos via physiological changes in the maternal environment that lead to an increase in intracellular oxidative stress on the embryo.

mammalian species, including sheep (Dutt, 1963), pigs (Wildt et al., 1975) and laboratory animals, such as mice (Baumgartner and Chrisman, 1987) and rats (Narendranath and Kiracofe, 1975).

In vitro culture systems that directly expose embryos to high temperatures have demonstrated a correlation of the vulnerability of early embryos to heat stress with a stagedependent acquisition of thermotolerance (Edwards et al., 2001). In cultured mouse embryos, thermotolerance can be induced by short-term heat shock at the eight-cell (Ealy and Hansen, 1994) or morula stage (Aréchiga et al., 1998), but not at the one- or two-cell stage. Furthermore, developmental acquisition of thermotolerance is associated with the ability of embryos to produce glutathione. Embryos cannot synthesize glutathione until the morula or blastocyst stage (Gardiner and Reed, 1995), and the inhibition of glutathione synthesis reduces the thermotolerance of heatshocked embryos at the morula stage (Aréchiga et al., 1995).

High body temperatures (Ikeda et al., 1999) and high metabolic rates (Ji, 1999; Niess et al., 1999) lead to increased production of reactive oxygen species (ROS), which react with various molecules in cells, such as lipids, proteins and nucleic acids, and result in cellular injury (Lin et al., 1991; Wills et al., 1997). Early cleavage-stage embryos are sensitive to oxidative stress and ROS inhibit embryonic development, inducing cellular fragmentation and degeneration (Nasr-Esfahani et al., 1990; Fujitani et al., 1997; Takahashi et al., 1999; Guérin et al., 2001). These 
reports support the hypothesis that oxidative stress is a direct cause of heat-stress-induced early embryonic loss. However, direct evidence has not yet been obtained for embryos that have been maternally heat-stressed in vivo. In the present study, the disruption of embryonic development in mice after maternal heat stress at the zygote stage was investigated to determine whether it is associated with changes in embryonic glutathione and $\mathrm{H}_{2} \mathrm{O}_{2}$ concentrations. In addition, the study examined whether the adverse effects of maternal heat stress could be reproduced by direct exposure of zygotes to a similar high temperature under culture conditions in vitro.

\section{Materials and Methods}

\section{Animals}

Eight- to 12-week-old male and female ICR mice and male $\mathrm{BDF}_{1}$ mice were purchased from Charles River Japan Inc. (Yokohama). Mice were housed at $25^{\circ} \mathrm{C}$ and $50 \%$ relative humidity with a $12 \mathrm{~h}$ light: $12 \mathrm{~h}$ dark photoperiod (lights on at 06:00 h) until they were used in experiments. All experimental protocols and animal handling procedures were reviewed and approved by the Animal Care and Use Committee of the University of Tsukuba.

\section{Materials}

Mineral oil, hyaluronidase, glutathione (reduced form), glutathione disulphide reductase, $\beta$-nicotinamide adenine dinucleotide phosphate (reduced form; NADPH), 5, 5' dithio-bis-2-nitrobenzoic acid (DTNB), $\mathrm{Na}_{2}$-EDTA and $2^{\prime}, 7^{\prime}$-dichlorodihydro-fluorescein diacetate (DCHFDA) were purchased from Sigma Chemical Co. (St Louis, MO). Equine chorionic gonadotrophin (eCG, serotrophin) and hCG (gonadotrophin) were purchased from Teikokuzouki Pharmaceutical Co. (Tokyo). Potassium simplex optimized medium (KSOM) was purchased from Specialty Media (Phillipsburg, NJ).

\section{Disruption of normal embryonic development by maternal heat stress}

Female ICR mice were kept overnight with males of the same strain, and mating was verified at 06:00 h on the next day by the presence of a vaginal plug (designated as day 1 of pregnancy). The mated females were then assigned randomly to one of the following three treatment groups: (i) heat-stressed on day 1 only (day 1 heat), (ii) successively heat-stressed from day 1 to day 3 (successive heat) and (iii) non-stressed (control). Mice in the heat-stressed groups were exposed to a high ambient temperature of $35^{\circ} \mathrm{C}$ with $60 \%$ relative humidity for $12 \mathrm{~h}$ during the light period. Subsequently, ten mice per group were killed by cervical dislocation on day 2 , day 3 and day 4 , and embryos were collected by flushing the oviducts and uteri with PBS. The morphology of collected embryos was noted and their developmental stages were confirmed.
Assessment of developmental ability of maternally and directly heat-stressed zygotes

Female ICR mice were superovulated by i.p. injection of 5 iu eCG at 12:00 h, followed by an i.p. injection of 5 iu hCG $48 \mathrm{~h}$ later. Female mice were then mated with BDF $_{1}$ males during the dark period. After observation of a vaginal plug on the subsequent day at 06:00 $\mathrm{h}$, ten mated females were exposed to heat stress $\left(35^{\circ} \mathrm{C}\right.$ and $60 \%$ relative humidity) for $12 \mathrm{~h}$ during the light period on day 1 (maternal heat stress). Another ten mated female mice were housed at $25^{\circ} \mathrm{C}$ and $50 \%$ relative humidity (control). At 18:00 h on day 1 , mice in each group were killed and embryos were collected by flushing oviducts with KSOM (Warner et al., 1998). Subsequently, embryos were washed three times in fresh KSOM and cultured in groups of 20 in $50 \mu \mathrm{l} \mathrm{KSOM}$ under mineral oil at $37.5^{\circ} \mathrm{C}$ in $5 \% \mathrm{CO}_{2}$ in humidified air for $84 \mathrm{~h}$.

Another 20 mated mice were killed at 06:00 h on day 1 and zygotes were recovered from the oviducts. Cumulus cells were eliminated by culturing zygotes in KSOM with $0.3 \mathrm{mg}$ hyaluronidase $\mathrm{ml}^{-1}$ for $2 \mathrm{~min}$. Subsequently, zygotes were rinsed three times in fresh $\mathrm{KSOM}$ to remove the enzyme and cultured in KSOM under mineral oil. Zygotes from ten mice were cultured at $39.5^{\circ} \mathrm{C}$ in $5 \% \mathrm{CO}_{2}$ for $12 \mathrm{~h}$ on day 1 , followed by ordinal culture at $37.5^{\circ} \mathrm{C}$ in $5 \% \mathrm{CO}_{2}$ for $84 \mathrm{~h}$ (in vitro heat stress). Zygotes from the other ten mice were cultured at $37.5^{\circ} \mathrm{C}$ in $5 \% \mathrm{CO}_{2}$ throughout the entire culture period (control).

The developmental ability of zygotes in each treatment group was assessed by determining the proportion of embryos that developed to the two-cell stage (fertilization rate) and the proportion of embryos that reached the morula or blastocyst stage (normal developmental competence).

\section{Monitoring of rectal temperature}

In the preliminary experiments, the rectal temperature was measured at $0,1,6,12$ and $13 \mathrm{~h}$ after the onset of maternal heat stress for $12 \mathrm{~h}$ with a thermistor instrument (D611; Takara Thermistor Co., Tokyo) by inserting a probe $1 \mathrm{~cm}$ in length into the rectum for $20 \mathrm{~s}$. The results indicated that the rectal temperature during heat stress varied among animals but did not differ during the period of heat stress. Average rectal temperatures at 1,6 and $12 \mathrm{~h}$ after the onset of heat stress ranged from $39.5^{\circ} \mathrm{C}$ to $39.6^{\circ} \mathrm{C}$, and returned to normal $\left(37.7^{\circ} \mathrm{C}\right.$ at $0 \mathrm{~h}$ ) within $1 \mathrm{~h}$ after heat stress (data not shown). Therefore, in the present study, rectal temperature was monitored inside an environment chamber for each animal once a day at 18:00 $\mathrm{h}$ (immediately before the end of heat stress).

\section{Assay for intracellular glutathione and $\mathrm{H}_{2} \mathrm{O}_{2}$ concentrations}

Embryos were exposed to maternal or direct heat stress for $12 \mathrm{~h}$ as described above. In the maternally heat-stressed group, zygotes were recovered soon after treatment (at 18:00 h on day 1), and two-cell embryos were recovered at 06:00 h on day 2 . In the in vitro group, zygotes were prepared at 18:00 h on day 1 of culture, and two-cell embryos 
Table 1. Percentage of normal embryos recovered from intact mice exposed to maternal heat stress on day 1 or from day 1 to day 3 of pregnancy

\begin{tabular}{|c|c|c|c|}
\hline \multirow[b]{2}{*}{ Group } & \multicolumn{3}{|c|}{$\begin{array}{l}\text { Day of pregnancy at embryo recovery } \\
\text { (normal developmental stages) }\end{array}$} \\
\hline & $\begin{array}{c}\text { Day } 2 \\
\text { (two-cell stage) }\end{array}$ & $\begin{array}{c}\text { Day } 3 \\
\text { (four- to } \\
\text { eight-cell stage) }\end{array}$ & $\begin{array}{l}\text { Day } 4 \\
\text { (morula or } \\
\text { blastocyst) }\end{array}$ \\
\hline Control & $90.4 \pm 3.8$ & $78.5 \pm 4.3^{a}$ & $97.8 \pm 1.4^{a}$ \\
\hline Heat stress on day 1 & $77.2 \pm 6.4$ & $4.7 \pm 2.5^{\mathrm{c}}$ & $12.5 \pm 7.6^{b}$ \\
\hline Heat stress from day 1 to day 3 & - & $12.3 \pm 3.8^{b}$ & $3.7 \pm 1.9^{c}$ \\
\hline
\end{tabular}

at 06:00 $\mathrm{h}$ on day 2 of culture. Glutathione and $\mathrm{H}_{2} \mathrm{O}_{2}$ concentrations were then determined. Total glutathione concentrations were measured by the DTNB-glutathione disulphide reductase recycling assay as described by Anderson (1985). In brief, embryos were stored in groups of 20 in $5 \mu \mathrm{l}$ of 0.2 mol sodium phosphate buffer $\mathrm{I}^{-1}$ with $10 \mathrm{mmol} \mathrm{Na}_{2}$ EDTA $\mathrm{I}^{-1}$ and $5 \mu \mathrm{l}$ of $1.25 \mathrm{~mol}$ phosphoric acid $\mathrm{I}^{-1}$ in a $1.5 \mathrm{ml}$ microfuge tube. Assay samples were warmed at room temperature for $15 \mathrm{~min}$ after the addition and mixing of $350 \mu \mathrm{l}$ sodium phosphate containing $0.33 \mathrm{mg} \mathrm{NADPH} \mathrm{ml}^{-1}$,

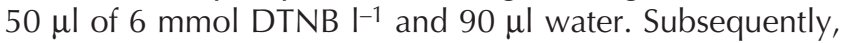
$5 \mu \mathrm{l}$ of $250 \cup$ glutathione disulphide reduc-tase $\mathrm{ml}^{-1}$ was added to the microfuge tube to initiate the re-action. Absorbance was recorded five times by spectrophotometer at $30 \mathrm{~s}$ intervals at $412 \mathrm{~nm}$. A glutathione standard and a sample blank were also assayed ( $n=7$ in each group).

The intracellular $\mathrm{H}_{2} \mathrm{O}_{2}$ concentration in the embryos was quantified by measuring $2^{\prime}, 7^{\prime}$-dichlorofluorescein fluorescence (Nasr-Esfahani et al., 1990; Nasr-Esfahani and Johnson, 1991; Yang et al., 1998; Hashimoto et al., 2000). A stock solution of DCHFDA, prepared in DMSO at $1 \times 10^{-3}$ mol I-1, was diluted in KSOM at $1 \times 10^{-5}$ mol I-1 immediately before the start of the assay. Embryos were incubated for $15 \mathrm{~min}$ in KSOM containing DCHFDA. Subsequently, embryos were rinsed three times in fresh $\mathrm{KSOM}$ to remove traces of DCHFDA, and were placed on a glass slide with KSOM and covered with a cover slip. The relative concentrations of intracellular $\mathrm{H}_{2} \mathrm{O}_{2}$ were measured using Analytical Imaging Station (Imaging Research Co., St Catharines, Ontario) after excitation at $480 \mathrm{~nm}$ and emission at $510 \mathrm{~nm}$ under a fluorescent microscope (BX 50; Olympus, Tokyo). The possible influence of assay protocol, which may increase intracellular $\mathrm{H}_{2} \mathrm{O}_{2}$ generation, was minimised by handling embryos under the lowest level of room light and fluorescence intensity was recorded $5 \mathrm{~s}$ after excitation of embryos.

\section{Statistical analysis}

Data were expressed as the mean \pm SEM. The percentages of embryos that were fertilized or which developed into mor- ulae or blastocysts were subjected to arc-sin-transformation and then analysed by one-way ANOVA followed by the Fisher's protected least significant difference test. The statistical significance of intracellular concentrations of glutathione and $\mathrm{H}_{2} \mathrm{O}_{2}$ in embryos was determined by Student's $t$ test. Differences were considered significant at $P<0.05$.

\section{Results}

Effect of maternal heat stress on embryonic development in vivo

The rectal temperature increased significantly in the maternally heat-stressed group $\left(39.8 \pm 0.2^{\circ} \mathrm{C}\right)$ compared with the control group $\left(37.8 \pm 0.1^{\circ} \mathrm{C}\right)(P<0.001)$. The percentages of normal developing embryos after maternal heat stress are presented (Table 1). The majority of recovered embryos in the control group were at the two-cell stage on day 2, the four- to eight-cell stage on day 3 and at the morula or blastocyst stage on day 4. Maternal heat stress on day 1 did not significantly affect the percentage of twocell embryos on day 2 , but resulted in a marked reduction in normal embryos after day 3. Successive heat stress from day 1 to day 3 produced similar results to those of day 1 heat stress. Most of the abnormal embryos in the heatstressed groups were arrested at the two-cell stage (34.7-53.4\% of total embryos) or had degenerated (11.6-16.9\%) on days 3-4. Although the rectal temperature in heat-stressed animals varied from $39.4^{\circ} \mathrm{C}$ to $40.3^{\circ} \mathrm{C}$, the heat-stress-induced embryonic loss did not correlate with the level of hyperthermia in individual animals.

\section{Effect of maternal heat stress and heat stress in vitro on first} cleavage and subsequent developmental ability of zygotes

The first cleavage rate of embryos was not affected by either maternal heat stress or in vitro heat stress (Fig. 1a). The percentage of embryos that reached the morula or blastocyst stage was significantly $(P<0.01)$ lower in the maternally heat-stressed group $(44.0 \pm 2.5 \%)$ than in the 

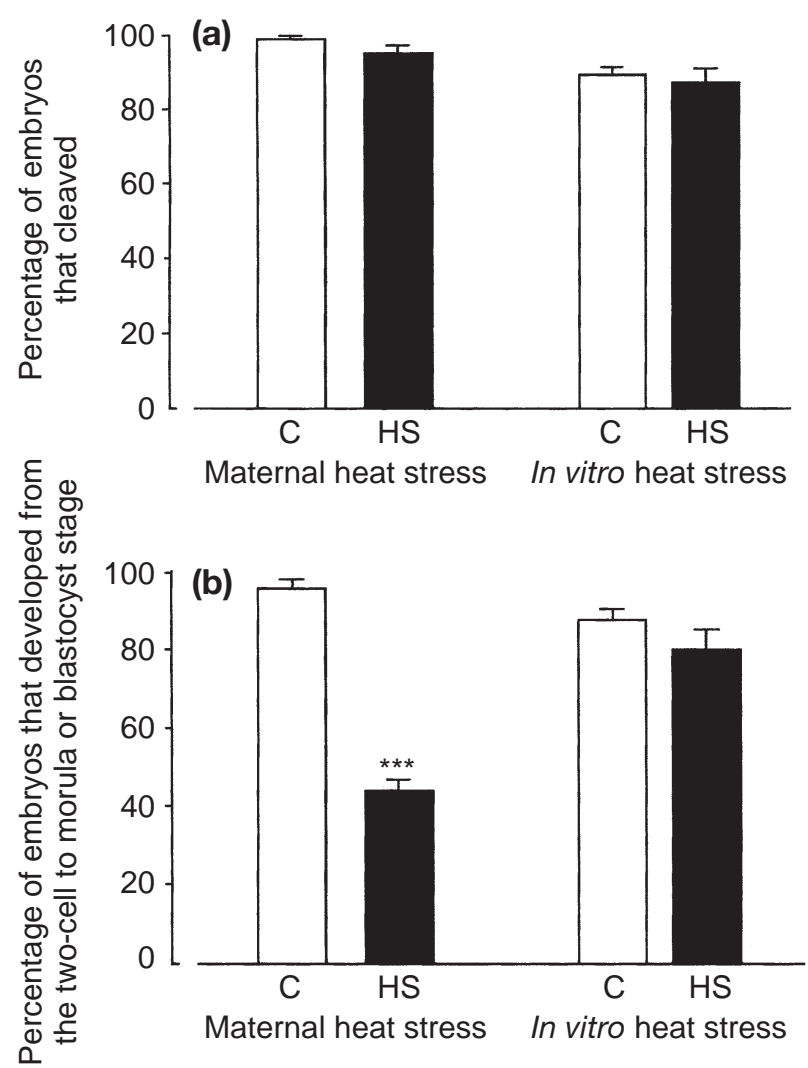

Fig. 1. Effects of maternal heat stress and in vitro heat stress on subsequent developmental ability of cultured mouse zygotes. (a) Percentage of embryos that cleaved. (b) Percentage of embryos that developed from the first cleavage stage to the morula or blastocyst stage. In the maternally heat-stressed groups, pregnant female mice were exposed to heat stress for $12 \mathrm{~h}$ on day $1(\mathrm{HS}, \mathbf{\square})$ or were untreated $(C, \square)$. Subsequently, embryos were recovered and cultured for $84 \mathrm{~h}$. In the in vitro heat-stressed groups, zygotes were recovered at $06: 00 \mathrm{~h}$ on day 1 and cultured at $39.5^{\circ} \mathrm{C}$ in $5 \% \mathrm{CO}_{2}$ for $12 \mathrm{~h}$, followed by ordinal culture at $37.5^{\circ} \mathrm{C}$ in $5 \% \mathrm{CO}_{2}(\mathrm{HS})$, or were cultured at $37.5^{\circ} \mathrm{C}$ in $5 \% \mathrm{CO}_{2}$ throughout the culture period (C). Values are expressed as mean \pm SEM of ten replicates. ***Significantly different from control $(P<0.001)$.

control group $(95.0 \pm 1.9 \%)$ (Fig. 1b). However, there was no significant change in embryonic development between zygotes that were directly heat-stressed in vitro $(87.5 \pm 3.6 \%)$ and control zygotes (89.5 $\pm 2.7 \%$ ) (Fig. 1b). In this experiment, the rectal temperature in the maternally heat-stressed group $\left(39.7 \pm 0.2^{\circ} \mathrm{C}\right)$ was significantly higher than that of the control group $\left(37.5 \pm 0.1^{\circ} \mathrm{C}\right)$. However, there was no apparent correlation between the rectal temperatures $\left(39.2-40.4^{\circ} \mathrm{C}\right)$ of individual heat-stressed animals, and the corresponding percentage of zygotes normally developed (30-55\%).

\section{Effect of heat stress on intracellular glutathione and $\mathrm{H}_{2} \mathrm{O}_{2}$ concentrations in embryos}

Intracellular glutathione concentrations were significantly lower in maternally heat-stressed embryos than in
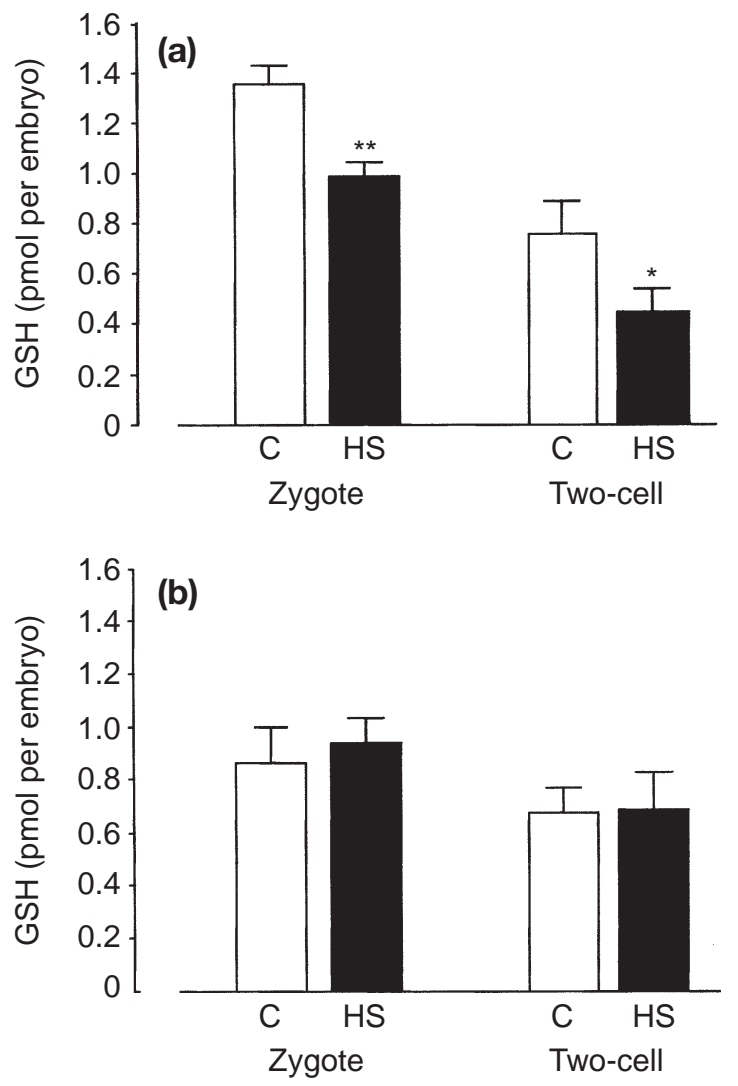

Fig. 2. Effect of (a) maternal heat stress or (b) in vitro heat stress on intracellular glutathione (GSH) concentrations of zygotes and twocell-stage mouse embryos. (a) Pregnant female mice were exposed to heat stress for $12 \mathrm{~h}$ on day 1 (HS, $\mathbf{\square})$ or were untreated $(\mathrm{C}, \square)$. Zygotes used for GSH assay were recovered soon after treatment (at 18:00 $\mathrm{h}$ on day 1), and two-cell embryos were recovered at 06:00 $\mathrm{h}$ on day 2. (b) Zygotes were recovered at 06:00 $\mathrm{h}$ on day 1 and cultured at $39.5^{\circ} \mathrm{C}$ in $5 \% \mathrm{CO}_{2}$ for $12 \mathrm{~h}$, followed by ordinal culture at $37.5^{\circ} \mathrm{C}$ in $5 \% \mathrm{CO}_{2}(\mathrm{HS})$, or were cultured at $37.5^{\circ} \mathrm{C}$ in $5 \% \mathrm{CO}_{2}$ throughout the entire culture period (C). Zygotes used for GSH assay were prepared at 18:00 h on day 1 of culture, and twocell embryos were prepared at $06: 00 \mathrm{~h}$ on day 2 of culture. GSH concentrations were measured by 5,5'-dithio-bis-2-nitrobenzoic acid-glutathione reductase recycling assay. Values are expressed as mean \pm SEM of seven replicates. Values are significantly different from control $\left(* P<0.05\right.$ and $\left.{ }^{* *} P<0.01\right)$.

control embryos at both the zygote stage $(0.99 \pm 0.06$ versus $1.36 \pm 0.08$ pmol glutathione per embryo, respectively, $P<0.01)$ and the two-cell stage $(0.45 \pm 0.09$ versus $0.76 \pm 0.13$ glutathione pmol per embryo, respectively, $P<0.01$ ) (Fig. 2a). In contrast, there were no significant differences in glutathione concentrations between embryos that were directly heat-stressed in vitro and control embryos at the zygote stage $(0.86 \pm 0.13$ versus $0.93 \pm 0.10 \mathrm{pmol}$ glutathione per embryo, respectively) and the two-cell stage $(0.64 \pm 0.10$ versus $0.68 \pm 0.13$ pmol glutathione per embryo, respectively) (Fig. 2b).

Maternal heat stress enhanced $\mathrm{H}_{2} \mathrm{O}_{2}$ concentrations in 


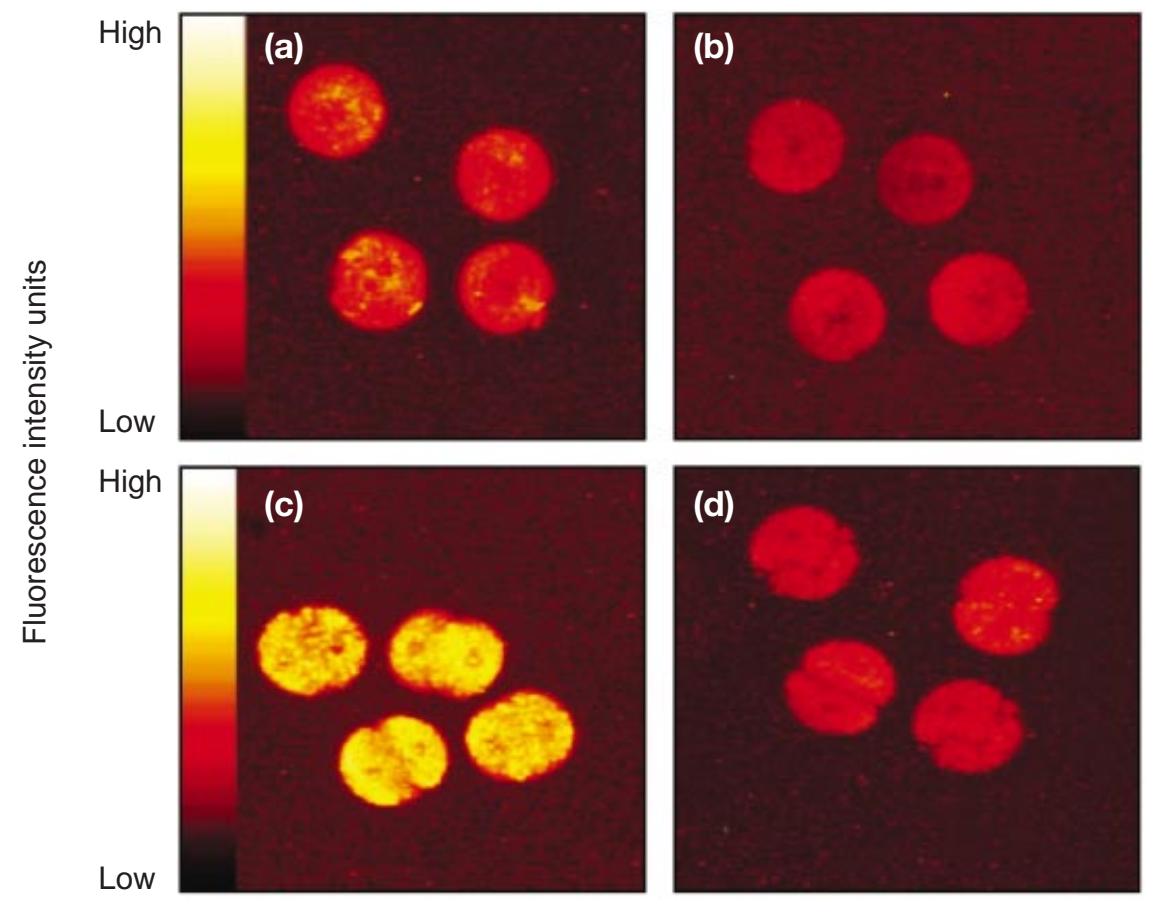

Fig. 3. Pseudocolour images of control and maternally heat-stressed mouse embryos after incubation for $15 \mathrm{~min}$ with $2^{\prime}, 7^{\prime}$-dichlorodihydro-fluorescein diacetate. Fluorescence intensity of $2^{\prime}, 7^{\prime}$-dichlorofluorescein, corresponding to intracellular $\mathrm{H}_{2} \mathrm{O}_{2}$ concentrations, is expressed in pseudocolour using Analytical Imaging Station according to the colour bar. (a) Maternally heat-stressed zygotes, (b) untreated zygotes, (c) maternally heat-stressed two-cell embryos and (d) untreated two-cell embryos.

embryos, as expressed by the fluorescence intensity of DCF (Fig. 3). Hydrogen peroxide concentrations were significantly higher in maternally heat-stressed embryos compared with control embryos at both the zygote and two-cell stages $(0.22 \pm 0.01$ versus $0.17 \pm 0.01$ fluorescence intensity units (FIU) per embryo for zygote, $P<0.01$ and $0.25 \pm$ 0.03 versus $0.18 \pm 0.01 \mathrm{FIU}$ per embryo for two-cell stage, $P<0.05$, respectively, Fig. 4a). In contrast, direct heat stress did not affect intracellular $\mathrm{H}_{2} \mathrm{O}_{2}$ levels of embryos at either the zygote or the two-cell stage (Fig. 4b). Maternal heat stress resulted in a significant increase $(P<0.001)$ in rectal temperatures $\left(39.7 \pm 0.2^{\circ} \mathrm{C}\right.$ for glutathione and $39.4 \pm 0.1^{\circ} \mathrm{C}$ for $\mathrm{H}_{2} \mathrm{O}_{2}$ ), but there were no consistent correlations between the degree of hyperthermia in individual animals and glutathione or $\mathrm{H}_{2} \mathrm{O}_{2}$ concentrations in the corresponding embryos.

\section{Discussion}

The results of the present study demonstrated that the detrimental effects of maternal heat stress on zygotes are not necessarily related to high body temperatures, but are mediated through physiological changes in the maternal environment or interaction between the zygote and its surroundings. Results from this study also provide direct evidence that the developmental arrest of maternally heat- stressed zygotes is associated with an increase of intracellular oxidative stress, as shown by the increase in intracellular $\mathrm{H}_{2} \mathrm{O}_{2}$ concentrations and the reduction of glutathione content within the embryos.

It is known that mammalian preimplantation embryos, particularly zygotes, are sensitive to heat stress, and that exposure of animals to hot environments soon after fertilization leads to an increase in the loss of early stage embryos (Dutt, 1963; Badinga et al., 1985; Ealy et al., 1993). It has also been demonstrated that direct exposure of cultured early embryos to temperatures of $41-43^{\circ} \mathrm{C}$ results in developmental arrest and an increase in embryonic death (Aréchiga et al., 1995; Ealy et al., 1995). The similarity between maternal heat stress and in vitro heat stress, that is, the vulnerability of zygotes to high temperatures, was considered to be a main cause for heat-stress-induced early embryonic death. However, the rectal temperatures of milking cows that are heat-stressed in the field are about $40-40.5^{\circ} \mathrm{C}$ (Rivera and Hansen, 2001), which are similar to those observed in the present study (rectal temperatures of heat-stressed mice were on average $39.4-39.7^{\circ} \mathrm{C}$ ). Thus, the high temperatures previously adopted for several in vitro experimental models of early embryonic death might be higher than those experienced in heat-stressed animals under field conditions. Ryan et al. (1992) reported that culturing bovine zygotes at $40^{\circ} \mathrm{C}$ did not compromise 

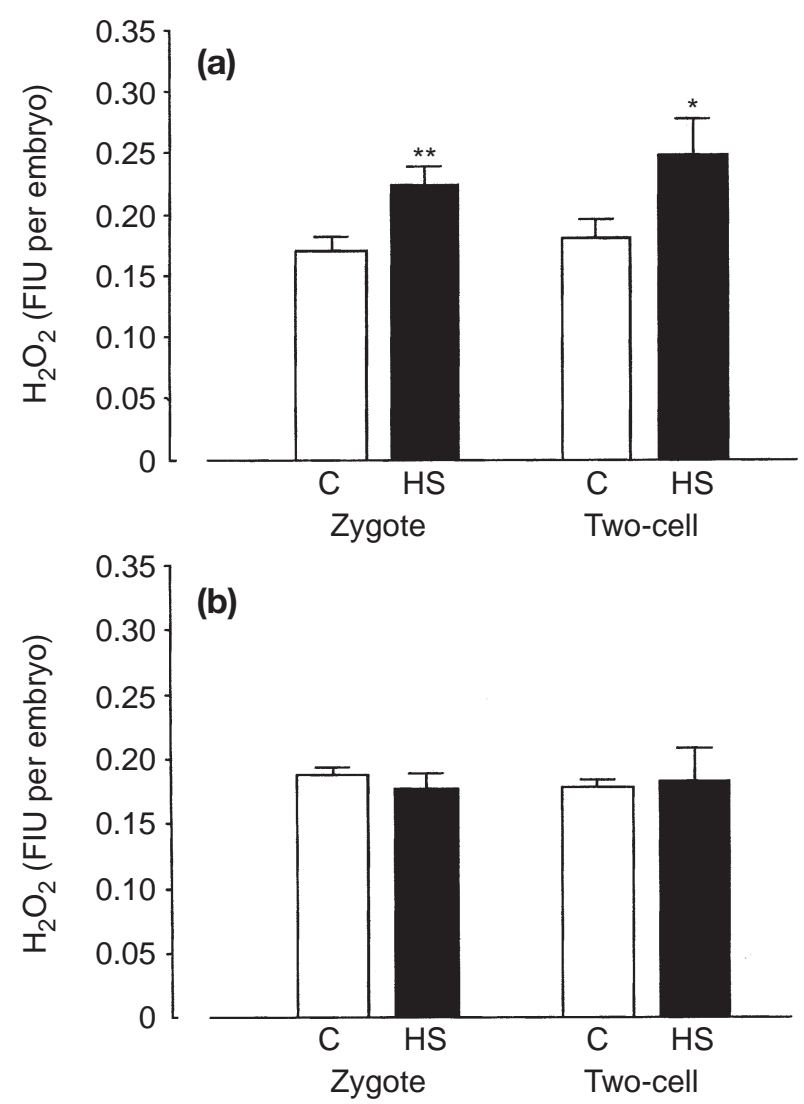

Fig. 4. Effects of (a) maternal heat stress and (b) in vitro heat stress on intracellular $\mathrm{H}_{2} \mathrm{O}_{2}$ concentrations of zygotes and two-cell mouse embryos. Embryos were heat-stressed maternally or in vitro and cultured at $39.5^{\circ} \mathrm{C}$ in $5 \% \mathrm{CO}_{2}$ for $12 \mathrm{~h}$, followed by ordinal culture at $37.5^{\circ} \mathrm{C}$ in $5 \% \mathrm{CO}_{2}(\mathrm{HS}, \mathbf{\square})$, or were cultured at $37.5^{\circ} \mathrm{C}$ in $5 \% \mathrm{CO}_{2}$ throughout the entire culturing period (C, $\square$ ). $\mathrm{H}_{2} \mathrm{O}_{2}$ concentrations were quantified by measuring $2^{\prime}, 7^{\prime}$-dichlorofluorescein fluorescence. Values represent arbitrary fluorescence intensity units (FIU). Values are expressed as mean \pm SEM of seven replicates (each performed in 6-9 embryos). Values are significantly different from controls $\left({ }^{*} P<0.05\right.$ and $\left.{ }^{* *} P<0.01\right)$.

subsequent development, and Rivera and Hansen (2001) revealed that exposure of bovine zygotes to a fluctuating high temperature that carefully mimicked the rectal temperature of heat-stressed cows for $12 \mathrm{~h}$ did not affect first cleavage and development to the blastocyst stage. These reports support findings of the present study, which demonstrate that developmental arrest or preimplantation embryonic death in hyperthermic animals might be caused by an interaction with the maternal reproductive tracts (for example, oviducts), and not by high temperature alone. It is possible that maternal heat stress changes the physiological conditions of the oviducts. Fallopian tubal fluid normally contains many ions and macromolecules, such as growth factors and anti-oxidants (Kane et al., 1997; Guérin et al., 2001; Leese et al., 2001), that are necessary for embryo survival and subsequent development. Further studies to analyse the effect of maternal heat stress on the reproductive tracts are required.
The data obtained in the present study revealed that maternal heat stress for $12 \mathrm{~h}$, which induced hyperthermia at about $39.5^{\circ} \mathrm{C}$ as determined by rectal temperatures, reduced intracellular glutathione concentrations and increased $\mathrm{H}_{2} \mathrm{O}_{2}$ concentrations in zygotes recovered immediately after heat stress and in subsequent two-cell embryos. High temperatures enhance the production of free radicals in both somatic cells (Lin et al., 1991; Ji, 1999) and germ cells (Ikeda et al., 1999). In testicular germ cells, heat stress increases the intracellular $\mathrm{H}_{2} \mathrm{O}_{2}$ concentration and induces apoptosis (Ikeda et al., 1999). An increase in free radicals is critical for cultured embryos and often leads to developmental arrest (Fujitani et al., 1997; Takahashi et al., 1999) or embryo degeneration (Nasr-Esfahani et al., 1990; Yang et al., 1998; Guérin et al., 2001). Glutathione, an antioxidant tripeptide, scavenges $\mathrm{H}_{2} \mathrm{O}_{2}$, and plays a critical role in the normal development of preimplantation embryos. Supplementation of culture medium with glutathione increases the resistance of bovine embryos to heat shock at $42^{\circ} \mathrm{C}$ in vitro (Ealy et al., 1992). Aréchiga et al. (1995) reported that in mouse embryos, glutathione-dependent mechanisms limit the deleterious effects of heat stress.

Unlike somatic cells, preimplantation embryos cannot synthesize glutathione de novo (Gardiner and Reed, 1995). Therefore, the early embryos may be very sensitive to oxygen stress, even at low concentrations. The results from the present study show that intracellular $\mathrm{H}_{2} \mathrm{O}_{2}$ concentrations were consistently higher in zygotes and in two-cell embryos recovered from heat-stressed animals compared with $\mathrm{H}_{2} \mathrm{O}_{2}$ concentrations in zygotes and two-cell embryos from non-stressed animals or those directly heat-stressed in vitro. This enhanced ROS generation was apparently correlated with a more severe reduction in glutathione concentration in two-cell embryos obtained from heat-stressed animals. This finding indicates the possible involvement of oxidative stress in maternal heat-stress-induced early embryonic death. It is also important to note that an increase in ROS in early embryos occurs at a lower temperature in the maternal environment compared with that observed in vitro. Further studies are required to identify factor(s) influencing the intracellular oxidative status of early embryos in the maternal environment.

Embryo genome activation, which occurs during the late one-cell and two-cell stages (Latham, 1999), is essential for normal embryonic development. When oxidative stress occurs before and during embryo genome activation, embryonic development is arrested at the two-cell stage (Nasr-Esfahani et al., 1990). A two-cell block and an increased oxidative state in maternally heat-stressed zygotes were observed in the present study. Haraguchi et al. (1999) reported that initiation of embryo genome activation was delayed in phosphate-induced two-cell-blocked embryos and speculated that the time lag for the onset of embryo genome activation may be the cause of the two-cell block. Therefore, it is important to determine whether the developmental arrest caused by maternal heat stress is associated with a disturbance in embryo genome activation. 
The authors thank I. Ohshima for her kind assistance, M. Kajihara for her generous guidance with embryo culture and N. Minami for technical advice concerning $\mathrm{GSH}$ and $\mathrm{H}_{2} \mathrm{O}_{2}$ assays. This work was supported by the Grant-in-Aid for Exploratory Research from Japanese Society for the Promotion of Science to Y. Kanai and in part by grant from Morinaga Hoshikai to M. Hirabayashi.

\section{References}

Anderson ME (1985) Determination of glutathione and glutathione disulfide in biological samples. In Glutamate, Glutamine, Glutathione and Related Compounds pp 548-555 Ed. A Meister. Academic Press, New York

Aréchiga CF, Ealy AD and Hasen PJ (1995) Evidence that glutathione is involved in thermotolerance of preimplantation murine embryos Biology of Reproduction 52 1296-1301

Aréchiga CF, Ealy AD and Hansen PJ (1998) Response of preimplantation murine embryos to heat shock as modified by developmental stage and glutathione status In Vitro Cellular and Developmental Biology Animal 34 655-659

Badinga L, Collinear RJ, Thatcher WW and Wilcox CJ (1985) Effect of climatic and management factors on conception rate of dairy cattle in a subtropical environment Journal of Dairy Science 68 78-85

Baumgartner AP and Chrisman CL (1987) Embryonic mortality caused by maternal heat stress during mouse oocyte maturation Animal Reproduction Science 14 309-316

Berman A, Folman Y, Kaim M, Mamen M, Herz Z, Wolfenson D, Arieli A and Graber Y (1985) Upper critical temperatures and forced ventilation effects for high-yielding dairy cows in a subtropical climate Journal of Dairy Science 68 1488-1495

Cavestany D, El-Wishy AB and Foote RH (1985) Effect of season and high environmental temperature on fertility of Holstein cattle Journal of Dairy Science 68 1471-1478

Dutt RH (1963) Critical period for early embryo mortality in ewes exposed to high ambient temperature Journal of Animal Science 22 713-719

Ealy AD and Hansen PJ (1994) Induced thermotolerance during early development of murine and bovine embryo Journal of Cellular Physiology 160 463-468

Ealy AD, Drost M, Barros CM and Hansen PJ (1992) Thermoprotection of preimplantation bovine embryos from heat shock by glutathione and taurine Cell Biology International Reports 16 125-131

Ealy AD, Drost $\mathbf{M}$ and Hansen PJ (1993) Developmental changes in embryonic resistance to adverse effects of maternal heat stress in cows Journal of Dairy Science $\mathbf{7 6}$ 2899-2905

Ealy AD, Howell JL, Monterroso VH, Aréchiga CF and Hansen PJ (1995) Developmental changes in sensitivity of bovine embryos to heat shock and use of antioxidants as thermoprotectants Journal of Animal Science 73 1401-1407

Edwards JL, King WA, Kawarsky SJ and Ealy AD (2001) Response of early embryos to environmental insults: potential protective roles of HSP70 and glutathione Theriogenology 55 209-223

Fujitani Y, Kasai K, Ohtani S, Nishimura K, Yamada M and Utsumi K (1997) Effect of oxygen concentration and free radicals on in vitro-produced bovine embryos Journal of Animal Science 75 483-489

Gardiner CS and Reed DJ (1995) Synthesis of glutathione in the preimplantation mouse embryo Archives of Biochemistry and Biophysics 318 30-36

Guérin P, El-Mouatassim S and Ménézo Y (2001) Oxidative stress and protection against reactive oxygen species in the pre-implantation embryo and its surroundings Human Reproduction Update 7 175-189

Hansen PJ, Drost M, Rivera RM, Paula-Lopes FF, Al-Katanai YM, Krininger CE, 3rd and Chase CC, Jr (2000) Adverse impact of heat stress on embryo production: causes and strategies for mitigation Theriogenology 55 91-103

Haraguchi S, Naito K and Sato E (1999) Phosphate exposure during the late 1 -cell and early 2 -cell stages induces a time-specific decrease in cyclin $\mathrm{B}$ and cdc25B mRNAs in AKR/N mouse embryos in vitro. Zygote 7 87-93
Hashimoto S, Minami N, Yamada M and Imai H (2000) Excessive concentration of glucose during in vitro maturation impairs the developmental competence of bovine oocyte after in vitro fertilization: relevance to intracellular reactive oxygen species and glutathione contents Molecular Reproduction and Development 55 520-526

Ikeda M, Kodama H, Fukuda J, Shimizu Y, Murata M, Kumagai J and Tanaka T (1999) Role of radical oxygen species in rat testicular germ cell apoptosis induced by heat stress Biology of Reproduction 61 393-399

Ingraham RH, Gillette DD and Wagner WD (1974) Relationship of temperature and humidity to conception rate of Holstein cows in a subtropical climate Journal of Dairy Science 57 476-481

Ji LL (1999) Antioxidants and oxidative stress in exercise Proceedings of the Society for Experimental Biology and Medicine 222 283-292

Kane MT, Morgan PM and Coonan C (1997) Peptide growth factors and preimplantation development Human Reproduction Update 3 137-157

Latham KE (1999) Mechanisms and control of embryonic genome activation in mammalian embryos. In International Review of Cytology pp 71-124 Ed. KW Jeon. Academic Press, San Diego

Leese HJ, Tay JI, Reishl J and Downing SJ (2001) Formation of Fallopian tubal fluid: role of a neglected epithelium Reproduction 121 339-346

Lin PS, Qoamo S, Ho KC and Gladding J (1991) Hyperthermia enhances the cytotoxic effects of reactive oxygen species to Chinese hamster cells and bovine endothelial cells in vitro. Reproduction Research 126 43-51

Narendranath R and Kiracofe GH (1975) Effects of heat-stress in rats II: factor(s) responsible for reduced embryonic and/or fetal survival percentage Indian Journal of Physiology and Pharmacology 3 140-145

Nasr-Esfahani MH and Johnson MH (1991) The origin of reactive oxygen species in mouse embryos cultured in vitro. Development 113 551-560

Nasr-Esfahani MH, Aitken JR and Johnson MH (1990) Hydrogen peroxide levels in mouse oocytes and early cleavage-stage embryos developed in vitro and in vivo. Development 109 501-507

Niess AM, Dickhuth HH, Northoff H and Ferenbach E (1999) Free radicals and oxidative stress in exercise: immunological aspects Exercise Immunology Review $\mathbf{5}$ 22-56

Putney DJ, Mullins S, Thatcher WW, Drost M and Gross TS (1989) Embryonic development in superovulated dairy cattle exposed to elevated ambient temperatures between the onset of estrus and insemination Animal Reproduction Science 19 37-51

Rivera RM and Hansen PJ (2001) Development of cultured bovine embryos after exposure to high temperatures in the physiological range Reproduction 121 107-115

Ryan DP, Blakewood EG, Lynn JW, Munyakazi L and Godka RA (1992) Effect of heat-stress on bovine embryo development in vitro. Journal of Animal Science 70 3490-3497

Takahashi M, Saka N, Takahashi H, Kanai Y, Schultz RM and Okano A (1999) Assay of DNA damage in individual hamster embryos by comet assay Molecular Reproduction and Development 54 1-7

Warner CM, Exley GE, McElhinny AS and Tang C (1998) Genetic regulation of preimplantation mouse embryo survival The Journal of Experimental Zoology 282 272-279

Wildt DE, Riegle GD and Dukelow WR (1975) Physiological temperature response and embryonic mortality in stressed swine American Journal of Physiology 229 1471-1475

Wills PG, Kim PM, Laposa RR, Nicol CJ, Parman T and Winn LM (1997) Oxidative damage in chemical teratogenesis Mutation Research 396 $65-78$

Yang HW, Hwang KJ, Kwon HC, Kim HS, Choi KW and Oh KS (1998) Detection of reactive oxygen species (ROS) and apoptosis in human fragmented embryo Human Reproduction 13 998-1002

Received 2 April 2002.

First decision 4 June 2002.

Revised manuscript received 5 July 2002.

Accepted 8 August 2002. 